\title{
ROMIOSINI DE YANNIS RITSOS UN CLAMOR ESPERANZADO DE JUSTICIA
}

Cilly Müller de Inda

\section{a) LITERATURA NEOHELÉNICA}

"En la larga y accidentada vida del pueblo griego, la literatura neohelénica constituye la expresión de su etapa "moderna."

Presenta no escasos valores que, por factores diversos, limitaron su conocimiento en el exterior.

Dionisos Solomós es el primero en emplear la lengua hablada por el pueblo, en la gran poesía. Con la osadía engendrada por la fuerza de su nacionalismo valiente, pone un corte al largo y penoso problema del bilingüismo -aún hoy latente-, que había intentado inútilmente, imponer una lengua artificial y arcaizante, a la que no tenía acceso la población mayoritaria que, víctima de atropellos y vejámenes totalitarios, se había convertido en ignorante y analfabeta.

Junto a él, Andreas Kalvos, inspirado en la lucha nacional, lega una obra breve pero valiosa. Sobreviviente del espiritu clasicista, contribuye a la formación de Palamás, Psijaris y Kavafis, quienes marcan, en lo formal, una ruptura con la tradición y se abren a temas universales.

\section{b) GENERACIÓN DEL 30}

Un cambio radical en el panorama de las letras neogriegas se produce con su advenimiento.

"Sus representantes, llamados genéricamente modernos en Grecia, aspiran a superar las formas y recogen concepciones y procedimientos de las nuevas corrientes estéticas europeas. El surrealismo de Breton, Aragón y Eluard; el futurismo ruso de Maiakovski, el italianismo de Marinetti; el arte de Eliot, están presentes en ios primeros pasos de la poesía moderna. ${ }^{2}$

Figuras con posturas diferentes aparecen en esta generación. Seferis, por un lado, parte del simbolismo, adhiere a la "Poesía pura" de Valery y crea sin embargo una técnica y un mundo poético originales. Por otro, Embirikos, Engonópulos y Gatsos adhieren con plenitud a las técnicas surrealistas. Odisseas Elytis parte de este movimiento para encontrar un lenguaje propio.

\section{c) POEsía DE LA RESISTENCIA}

La Segunda Guerra Mundial (1939-1945) y los cuatro años de ocupación nazi siembran ruina, devastación y muerte en el territorio de la Hélade.

La ocupación, empero, no fue sometimiento y la resistencia se organizó en los montes, desde donde hostilizó al invasor.

Artistas $e$ intelectuales adoptan una actitud progresista activa frente a los problemas sociales y políticos del pais y toman un lugar en la lucha por la libertad: Kostas Thrakiotis, Nicéforo Vretakos y Yannis Ritsos. 


\section{d) YANNIS RITSOS}

"Es uno de los poetas más importantes de la Grecia contemporánea, y uno de los pocos que ha logrado trascender, por la universalidad de su lenguaje poético, los limites de su idioma y su geografía".

Nacido el 1 de mayo de 1909 en Monembasiá, en la región del Peloponeso, ha realizado una obra vastísima, prácticamente desconocida en castellano, que se inicia en 1934 con su libro Tractor, cuyo título sugiere una temprana definición ideológica.

En 1936 publica Epitafios, poemas inspirados en una masacre ocurrida en Salónica y en 1937 La canción de mi hermana, donde insinúa acentos de otro orden.

A esos primeros títulos sucede una nutrida serie de obras, entre las cuales pueden citarse El hombre del clavel (1952), Vigilia (1954), Sonata claro de luna (1956), Doce poemas para Kavafis (1963), Romiosini (1966), Fedra (1978), etc. También ha traducido a Bloch, Atila Josez, Nicolás Guillén y es además pintor, especialmente de cantos rodados y otros materiales.

Esta extensa obra ha sido distinguida con importantes premios, entre otros, el Nacional de Poesia, en 1956, el Alfred de Vigny, de París, en 1975, el Gran Premio Internacional de la Bienal de Bélgica en 1972 (...) Paralelamente a su labor literaria, Ritsos registra una intensa actividad política de izquierda que le ha traído aparejado el confinamiento en varios campos de concentración (...)

Esta militancia ha contribuido a cimentar su popularidad, favorecida también por la musicalización que Mikis Theodorakis hizo de muchos de sus textos.."

\section{e) APROXIMACIÓN A ROMIOSINI}

Obra madura que recoge toda la frustración y el descontento de un pueblo pobre, abatido, siempre de luto, rabioso, que se mantiene erguido gracias a su fidelidad inclaudicable ante la libertad, su lengua y la luz.

Los antiguos helenos pasaron a llamarse "romei" en tiempos bizantinos. "Romiós", según explica Horacio Castillo vino a designar "el punto de conjunción entre el antiguo helenismo y el cristianismo."

Seguiremos la versión castellana que el poeta Horacio Castillo incluye en la obra a la que aludimos, pues coincidimos en que la misma -según declaraciones del autor- ${ }^{5}$, "conserva (la) particularidad del lenguaje poético de Ritsos, evitando el embellecimiento sintáctico de algunos traductores franceses, o la desprolijidad expresiva de ciertas traducciones españolas."

CANTO I: Himno con sed de justicia en el que la Naturaleza, protagonista áspera, afirma un clamor que se universaliza.

El dolor acentúa las figuras que, próximas al poeta, adquieren presencia en esta poesia visual con el demostrativo "estos-estas".

Estos árboles no se arreglan con tan poco cielo, estas piedras no se arreglan bajo el paso extranjero, estos rostros no se arreglan sino con sol, estos corazones no se arreglan sino con justicia.

El verbo enmarca la escena en un tiempo perdurable con el reiterado uso del aspecto durativo. 
La inamovilidad se condensa en el grito sordo que abre la estrofa primera: $\mu \grave{\varepsilon}$ ßoudeviovtal (no se arreglan), expresado en voz media para acentuar la acción reflexiva de los elementos (árboles, piedras) que comparten la vigilia ante el sometimiento. caracteriza.

Desolación y silencio. El poema, desde su inicio, ofrece el clímax trágico que lo

Anhela el poeta la cosmogonía original que otrora conoció, plena de cielo, sol, agua y luz:
Este sitio es duro como el silencio, aprieta contra el pecho sus piedras calcinadas, aprieta contra la luz sus olivos huérfanos y sus viñas, aprieta los dientes. No hay agua. Solamente luz.
El camino se pierde en la luz y la sombra de la tapia es metálica. creación:

Obsesivamente, el verbo reiterado, acentúa la indignación que corroe a toda la

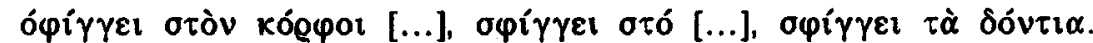

Aprieta contra el pecho $[\ldots]$, aprieta contra la luz $[\ldots]$, aprieta los dientes[...].

La tierra yerma no contiene agua pero estalla de luz, tema recurrente al que Ritsos volverá más de una vez.

Imposible no dejar de recordar que el amor por la luz, constante en la literatura griega clásica, donó versos inmortales en boca de Ifigenia o de Edipo.

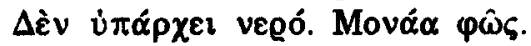

No hay agua. Solamente luz.

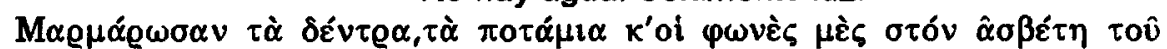

$\eta \eta_{1}$ เov.

Se petrificaron los árboles, los ríos y las voces en la cal del sol.

En este contexto angustioso, el hombre -que vive en empatía con la Naturaleza-, espera su reivindicación con la resurrección de la vida.

Patéticas imágenes describen a seres viriles, dolorosos y rudos que guardan la ternura en sus corazones, cargados de ilusiones:

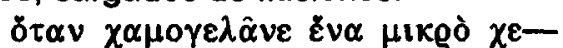

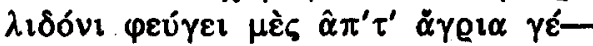

vela tous

Cuando sonríen una pequeña golondrina vuela de sus hirsutas barbas.

Acentúa el poeta el anti-climax, con la vigencia de tiempos durativos que destacan y prolongan la figura humana:

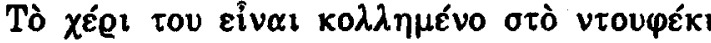

Sus manos están pegadas al fusil

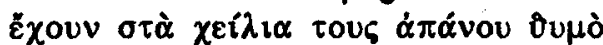

tienen los labios llenos de rabia. 
La vida en la militancia de la resistencia, dignifica la existencia mortal.

El uso del aoristo finitivo ${ }^{6}$ marca el corte y el crescendo:

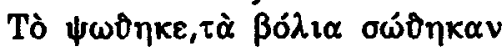

El pan se agotó, las balas se agotaron.

Abruptas acciones se refuerzan con dos adverbios impactantes: el temporal

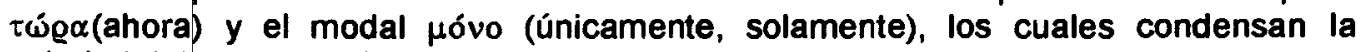
soledad del verso que los contiene:

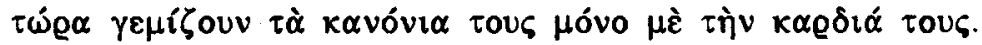

Ahora cargan los cañones sólo con sus corazones.

El imperio del aspecto durativo anuncia hechos trascendentes, que no tienen fin: la muerte engendra vida y ésta alimenta el espíritu, aún en circunstancias adversas:

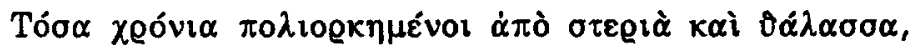

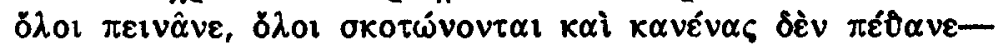

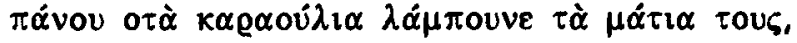

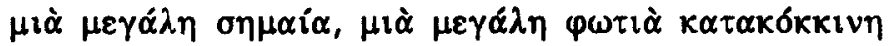

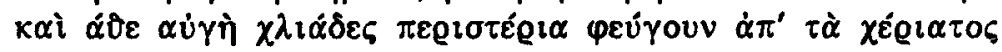

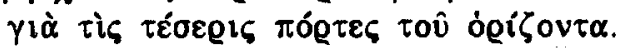

Tantos años sitiados por tierra y por mar,

todos tienen hambre, todos perecen, pero ninguno muere sus ojos brillan en las atalayas, ven una gran bandera, un gran fuego rojo y cada amanecer miles de palomas vuelan de sus manos hacia las cuatro puertas del horizonte.

Economia precisa la del autor para condensar, en el segundo verso, una gradación de sufrimientos que espiritualizan la carne masacrada:

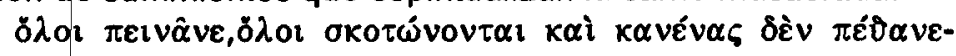

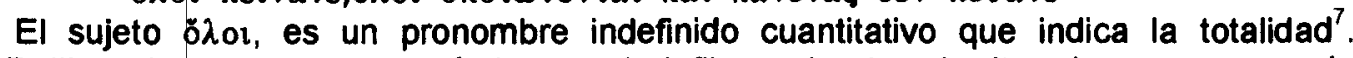
Deliberada es la carga semántica que le inflinge el autor al reiterarto para agravar la tensión dramática desoladora.

La falta de alimentos, expresada en el verbo $\pi \varepsilon \imath \hat{\alpha} v \varepsilon \varepsilon$ (tienen hambre) deriva en

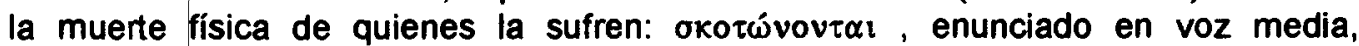
reflexiva, para subrayar que los actores "se mueren", "se oscurecen". Una antítesis esperanzadora concluye el verso con el uso de otro indefinido de matiz cualitativo:

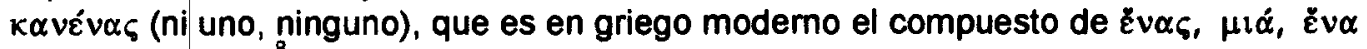
(uno, cualquiera) $)^{8}$.

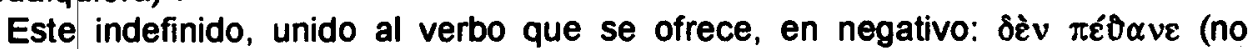
muere) marca la oposición a las acciones apuntadas anteriormente.

El hombre, invocado anónimamente, ha logrado triunfar sobre la materia; su ascesis se ha completado.

Imposible dejar de remarcar que Ritsos se solaza es esbozar diferentes matices que ya en el griego clásico estaban establecidos: 


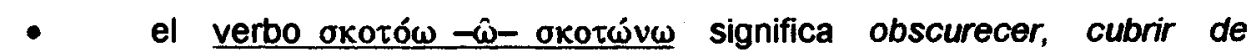
tinieblas. Recuérdese el sustantivo okó

El verbo, evidentemente, alude al ámbito infernal, el Hades, mundo tenebroso, oscuro y con brumas espesas en el que los muertos llevan una existencia triste y monótona, transformados en sombras que deambulan ${ }^{9}$. (Confrontar el canto $\Lambda$ de Odisea, seguramente inspirado en relatos tradicionales, el que ofrece una soberbia y realista descripción del lugar).

- el verbo ôviakw, raíz $\alpha v$ - en aoristo, puntualiza la idea de morir, perecer, desaparecer, dejar de existir.

El camino del héroe se ha cumplido y el poeta estalla de júbilo: Todos están en tinieblas (han descendido al Tártaro), pero ni siquiera uno muere.

Una plástica imagen, cargada de símbolos, marca el fin del primer canto y se expande a todo el universo: las manos se vuelven alas y éstas invaden el horizonte.

CANTO II: La fuerza telúrica es el eje y acicate de esta acuarela nocturna en la que el ojo del poeta rescata con minucioso deleite los elementos que la conforman.

El aspecto durativo de los verbos prolonga la quietud de la escena. Dolor y silencio sepulcrales amparan a los valientes que ostentan en su físico la raiz de su estirpe, en conjunción con el universo con el que se identifican.

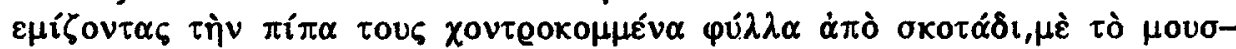

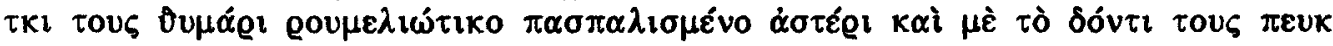

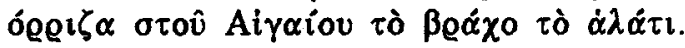

Cargando sus pipas con el tabaco picado de la noche, con sus bigotes de tomillo helénico espolvoreado en los astros y con sus dientes de raiz de pino clavada en la roca y la sal del Egeo.

Abruptamente, el uso de Aoristos ingresivos enmarca las acciones de estos hombres superiores, héroes conscientes del destino que los amalgama:

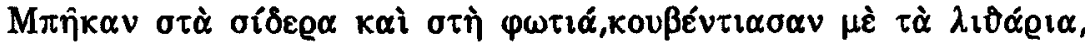

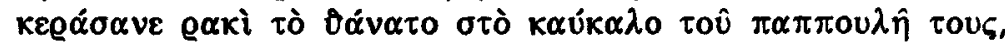

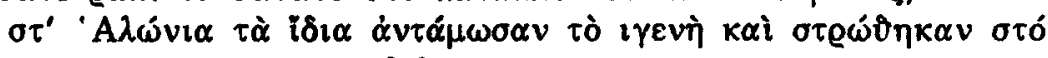

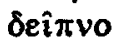

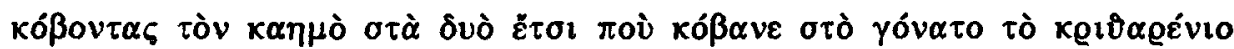

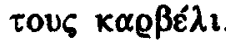

Entraron al hierro y al fuego, conversaron con las piedras, ofrecieron aguardientes a la muerte en la calavera de sus abuelos, encontraron a Digenis en las mismas eras y se sentaron a comer cortando el dolor en dos como cortaban sobre las rodillas el pan redondo.

Fuertes imágenes acordes con la dureza de la vida de quien está familiarizado con la muerte.

La inclusión del imperfecto kóßave (cortaban) acerca al presente la acción durativa que enuncia y marca un corte con los aoristos que lo preceden.

De aqui en más, Ritsos incluye un himno a una deidad, (que suponemos sea Atenea, de acuerdo con las cualidades que el poeta le asigna: patrona protectora; 
guerrera que empuña armas; porta el rayo; se mimetiza con la triste y dura mujer griega).

Se vislumbran reminiscencias de Safo en su himno a Afrodita, por el tono imperativo con el que la urge y el trato confiado en la divinidad. Con honda ternura, el autor implora a la virgen justiciera. La Naturaleza condensa la tensión trágica que empapa el aire. La curva ascensional que protagoniza el rojo mosto de las uvas, no sólo existe sino que "hierve": $\kappa \circ \lambda \alpha \dot{\zeta} \zeta \varepsilon$; contagia a la flor, que ha logrado sobrevivir en un rododendro ya quemado; expande subterránea la angustia del muerto que busca el

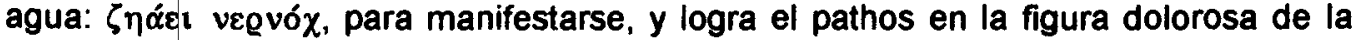

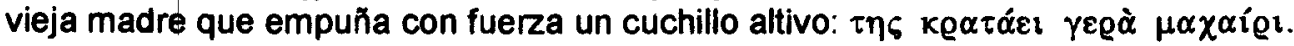

La creación toda deposita en la deidad la seguridad ciega de que será restablecido el orden para que todas las criaturas -aun las más indefensas-, gocen de paz:

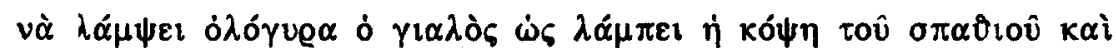

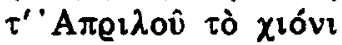

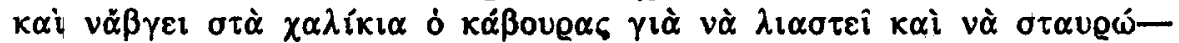

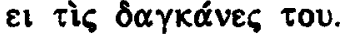

para que brille alrededor el mar como brilla el filo de la espada y la nieve de abril

para que el cangrejo salga entre los guijarros y se eche al sol con sus pinzas cruzadas.

El ansia de esperanza basada en la justicia vibra en la voz del poeta que alcanza su mayor tono lírico en estos últimos versos que condensan su petitorio.

La cadencia de iotas, unidas a silbantes y liquidas enuncia una melodía que se eleva sin tregua:

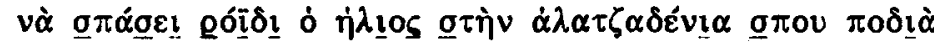

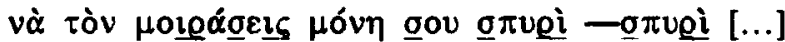

para que el sol estalle como una granada en tu celeste delantal y lo repartas grano a grano [...]

A este respecto, son enriquecedoras las acotaciones de $\mathrm{Karl}_{\text {Buhler }}{ }^{10}$ quien considera que los sonidos de los fonemas ofrecen una variedad de matices

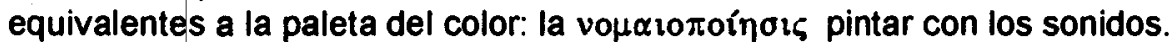

La frecuencia rítmica desarrollada por Ritsos se amalgama con un abanico colorido que desde el rojo sombrio del mosto de la uva pasa al negro tenebroso; se ilumina con el amarillo dorado y explota de luz en el azul de la esperanza liberadora que tiñe de celeste el delantal de la Señora invocada en esta pieza conmovedora y sutil. tempore"11.

CANTO II: Signos inequivocos reafiman el tiempo primordial, el "illo

* reiteración del adverbio temporal $\delta \hat{\omega}$ (aqui);

* seres celestes destacados: sol, cielo; 


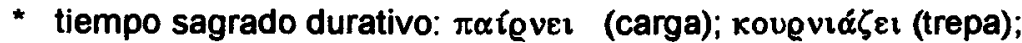

* unión de los contrarios: el cielo no consume nunca el aceite de nuestra mirada:

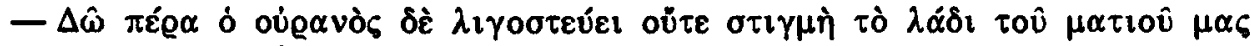
aqui el sol carga sobre sí la mitad del peso de la piedra [...]:

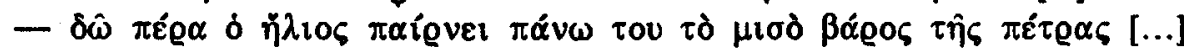
los hombres van delante de su sombra:

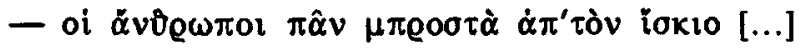

Ritsos se interna, como queda claro en los ejemplos seleccionados, en el mundo apasionante del adynaton, largamente estudiado por Ernest Dutoit ${ }^{12}$.

"La literatura greco-latina creó los adynata o impossibilia e hizo frecuente uso de esta forma de lenguaje," consigna Vicente Cichitti ${ }^{13}$.

En dicho trabajo meduloso, en el que abrevamos con frecuencia, el inolvidable maestro considera que: "Una entrañable solidaridad entre el hombre y la naturaleza se manifiesta cuando se mantiene el orden moral; cuando decae, el cosmos se deteriora en medio del desgaste producido en el orden humano."

Dada la afligente situación de injusticia social y política que le toca vivir a Ritsos, encuentra en el adynaton (al igual que Longo al que nos dedicáramos en otra oportunidad) ${ }^{14}$ "la $\dot{\alpha} \pi \circ$ ci $^{\alpha} \alpha$ imprescindible para reflejar el trastorno en la escala de valores que su época ofrece y la abolición de normas establecidas en el principio de la Creación."

" símbolos míticos sugerentes:

a) altura;

b) viejas que encarnan la tradición;

c) Gran piedra;

d) astros;

e) viento;

f) abismo;

g) comunicación entre fuerzas ascendentes y descendentes;

h) mensajero;

i) Gran Valle ${ }^{15}$;

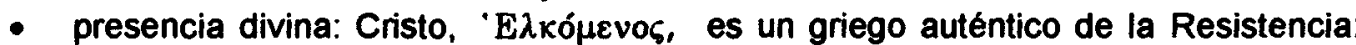
triste, con manos atadas, pero sediento de justicia:

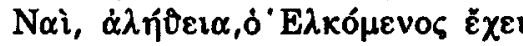

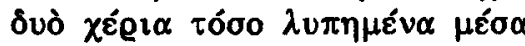

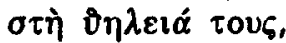

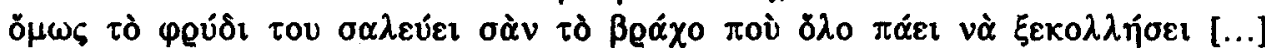

Si, es Cristo, el Cristo tiene las manos tan tristes entre las ligaduras, pero sus cejas tiemblan como una roca que va a precipitarse $[. .$.

Hondo lirismo detectamos en la penúltima estrofa. La reminiscencia del granadino Lorca, combativo y nacionalista como Ritsos, nos resulta evidente:

Ay, que sople una vez y arranque los naranjos del recuerdo,

ay, que sople dos veces y saque chispas de la piedra como un gatillo,

ay que sople tres veces y enloquezca los abetos del Parnaso 


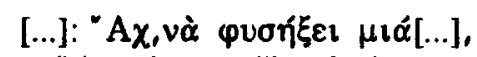

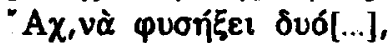

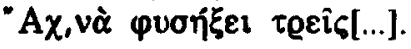

Una suave melodía acompaña el gemido contenido; el sonido es vital: la presencia reiferada de iotas suaviza la expresión de líquidas que se prolongan en silbantes:

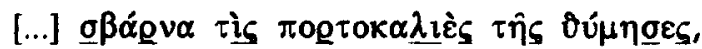

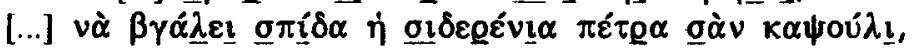

El lamento doloroso encarna un baile grotesco que se expresa en guturales tanto sordas como sonoras y marca contorsiones que crispan la piel y los oídos con filosas guturales aspiradas que vibran en sibilantes ruidosas:

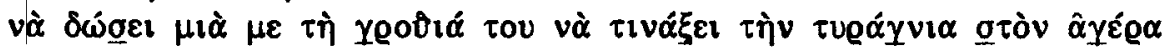

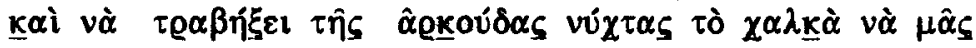

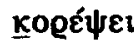

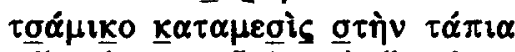

que haga saltar de un punetazo la tirania por los aires,

que arrastre de la cadena al oso de la noche para que nos baile un tsámico junto a la tapia

Significativo en su variedad polisémica, el canto III constituye la obertura de la magnífica gesta heroica que el autor desgranará a golpes de cincel en los cantos IV , $\checkmark$ y VI. No entraremos en el análisis de los mismos pero, para orientar a quien no tenga acceso al texto, consignaremos algunas referencias fundamentales.

Ofrece el autor un ejército apocalíptico que, altanero, desafía el tiempo, consciente de su misión liberadora. Encarnado en arquetipos del mundo, portan el cosmos en sus figuras dantescas:

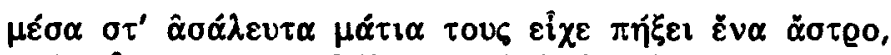

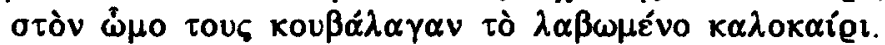
en sus ojos inmoviles se habia condensado una estrella, llevaban en sus hombros al verano herido.

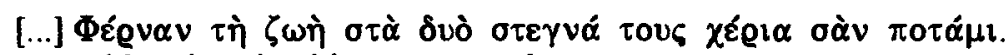
Llevaban la vida como un río en sus manos resecas.

Ostentan "la arena de la luna":

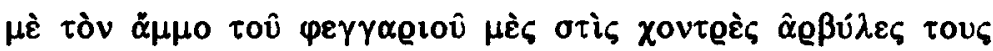

"y el carbón de la noche [...]":

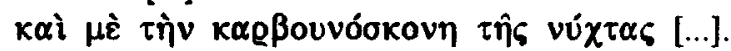

Generosos y endurecidos, sufren de pie sin doblegarse:

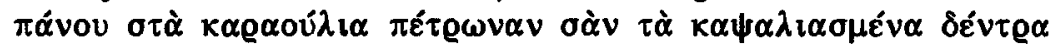
se quedaban petrificados en las atalayas como árboles quemados.

Con el orgullo de ser griego, exalta el autor la hombría de los soldados:

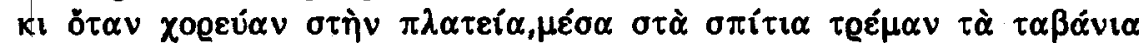

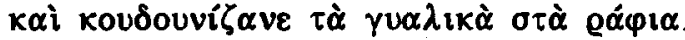

y cuando bailaban en la plaza, en las casas temblaba el cielo raso $y$ tintineaba la cristalerla en las repisas. 
Con profundo dolor $y$ sin detalles estériles, la derrota aparente $y$ el sojuzgamiento atroz invaden la escena. Conjunción de tierra y hombre ante la pérdida de su suelo natal (Recuérdese que para el griego del siglo $\mathrm{V}$ a.C., es ignominioso haber sido desterrado y a este propósito, Edipo al final de la tragedia sofloquea, llora no por el dolor de haberse arrancado sus propios ojos sino porque tendrá que vivir lejos de la tierra patria, sin que ninguno de los mortales pueda hablarle).

Ante el atroz avasallamiento, la luz - fuente de vida singular, en especial para el griego, como ya lo apuntamos-, se empobrece y opaca.

Localiza en el tiempo la contemporaneidad de los hechos que contrapone con el uso del adverbio $\tau \omega \omega_{\varrho} \alpha$ :ahora y consigna su consecuencia:

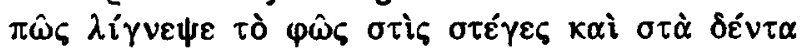

cómo disminuyó la luz en los techos y en los árbolesprofundo:

Un leiv-motiv doloroso condensa el enraizamiento a la tierra en un grito

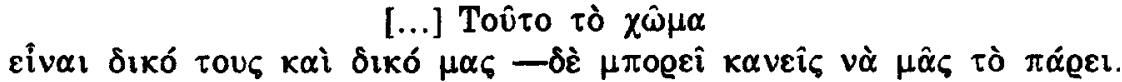

[...] Esta tierra es de ellos y de nosotros - nadie nos la podrá quitar.

El tema de la muerte es obsesivo. En delirio febril corroe al poeta, como a Antígona, el sufrimiento del hermano caído e insepulto:

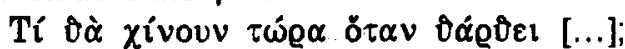

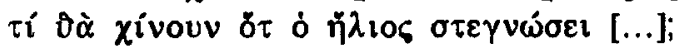

Qué será de ellos cuando la lluvia arroje $[. .$.$] ?$

Qué será de ellos cuando el sol se seque [...]?

A la desolación, opone Ritsos el valor inquebrantable de la mujer griega y exalta embelesado sus hazañas:

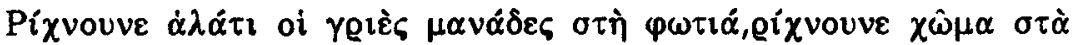
$\mu \alpha \lambda \lambda \iota_{1} \dot{\alpha} \tau o \cup \zeta$,

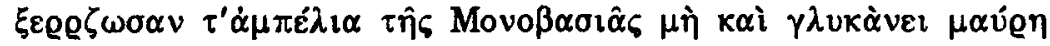

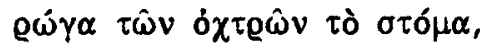

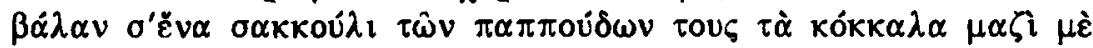
$\tau \grave{\alpha} \mu \alpha \chi \alpha \imath \varrho o \pi i \varrho o u v \alpha$

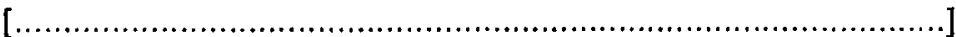

Viejas madres echan sal en el fuego, echan tierra en sus cabellos, Arrancan las vides de Monembasiá para que el negro racimo no endulce la boca de los enemigos,

pusieron en un saco los huesos de sus abuelos junto con los cubiertos

[..................................................................................]

Angustia ultrajada de la Naturaleza; desgarradoras pinceladas grafican el éxodo de los sobrevivientes a las montañas, bajo el amparo de las sombras:

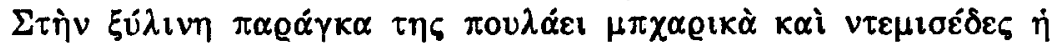

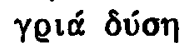

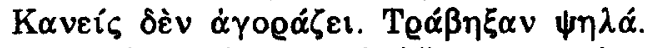

En su barraca de madera vende hilos y especias la vieja noche.

Nadie compra. Subieron a las montañas. 
La altura -como ya lo consignamos-, es el lugar donde se produce la hierofonia pues el resguardo de lo sagrado ${ }^{16}$.

Concluye el poema $\mathrm{VI}$ con bellísimas imágenes que reafirman la esperanza liberadora que anida en la Naturaleza:

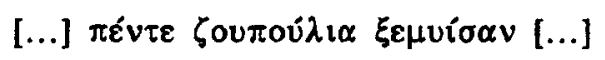

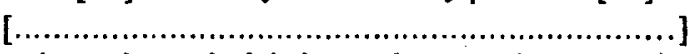

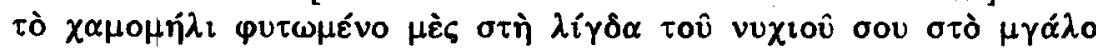

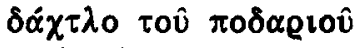

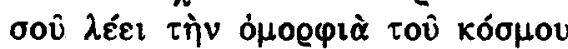

$[\ldots]$ cinco nardos asomaron [...]

[............................................................]

la manzanilla nacida en la uña del dedo gordo del pie te habla de la belleza del mundo.

El canto VII ofrece un mundo nuevo e idílico en el que:

- el pasado y el presente confluyen;

- la esperanza engendra fortaleza;

- la vida se prolonga en la muerte;

- el conocimiento es vía hacia la trascendencia;

- la naturaleza, maternal, ampara y vela por el hombre;

- la experiencia del dolor, unida a la del amor, se eleva en una confraternidad universal.

La lengua del poeta acentúa estas características significativas:

- el aspecto durativo de los verbos proyecta el tono a lo a-temporal, a lo que no tiene fin;

- los adverbios marcan oposiciones temporales que acercan a los contrarios:

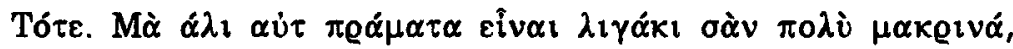

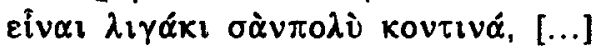

Entonces. Pero estas cosas están todavía muy leios,

Todavía muy cerca .[...]

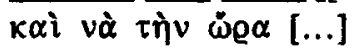

$y$ he aqui la hora [...]

Ritsos, en una sintesis exquisita, se despoja de lo accidental para dejar libe lo esencial. Nos hace partícipes del misterio y alli radica su grandeza.

\section{VALORACION FINAL}

Romiosini, poema profundo e inagotable sintetiza:

- la expresión social de un hecho histórico conmovedor. Podriamos decir, parodiando a Unamuno, que a Ristos le "duele" Grecia. Acota Octavio Paz que "EI poema, ser de palabras, va más allá de las palabras y la historia no agota el sentido del poema; pero el poema no tendría sentido $-y$ ni siquiera existencia- sin la historia, sin la comunidad que lo alimenta y a la que alimenta" ${ }^{n}$.

- Poesía epifánica que devela lo oculto de los seres.

- La observación de la physis permite el acceso al plano metafísico: el hombre, munido de libertad, es parte del cosmos. De la ambivalencia, su carácter trágico. 
- Presencia constante de Eros y Thanatos, con profundo sentido humanista: fe en el hombre y en la creación. "El poeta cree siempre en el valor de la vida porque, si realmente la considerara vana, no tendria valor para escribir" ${ }^{18}$.

- La muerte, para Ritsos, no es tan sólo la física sino "todas las formas de muerte social: la opresión, la esclavitud, las aspiraciones que no se cumplen (...) ${ }^{19}$. Interesante recordar que Federico García Lorca en "Teoria y juego del duende" sostiene que "el duende no llega si no ve la posibilidad de la muerte".

- El poema acentúa lo sustancial en su cosmogénesis;

- Privilegia la lengua coloquial, expresiva, que rescata la movilidad del verbo, "el elemento -dice- más dinámico de toda lengua". ${ }^{20}$

- Símbolos significativos e imágenes sensoriales y auditivas contribuyen a afirmar un orden nuevo en el que el autor confia.

- "pinta con los sonidos" utilizando la materia fónica.

- El contraste temporal sugiere una múltiple perspectiva de la acción verbal.

- La precisión de los matices de la sustancia verbal se logra con el preciso apoyo de los adverbios.

Hasta aquí, nuestro testimonio desnudo, directo, que no agota ni trasunta la entrañable riqueza expresiva del poema de Ristos. Afirmamos con Octavio Paz ${ }^{21}$, que "lo único que cuenta es la espontaneidad de las reacciones personales", las que, conmoviéndonos íntimamente, nos ayudan a dar el "salto mortal" y alcanzar la "otra orilla", pues, como consigna el humanista mexicano, "la recitación poética es una fiesta; una comunión"22, que, al reiterarla, nos permite salir de nuestra cárcel y avizorar la beatitud de la Belleza. 


\section{BIBLIOGRAFIA Y CITAS}

${ }^{1}$ CASTILLO DIDIER, Miguel. Antología de la lit. neohelénica- 1 Poesia. Santiago,Chile, Coedición Edit. Andrés Bello y Centro E.E. Bizantinos y Neohelénicos, 1971, ps. 23-24.

2 CASTILLO DIDIER, Miguel. Seferis, el poeta del país desaparecido. (En: Bizantion Nea Hellas -2- Univ. de Chile, Centro E.E. Bizantinos y Neohelénicos, 1971, p. 88).

${ }^{3}$ CASTILLO, Horacio. Traducción , selección y prólogo a : Romiosini y otros poemas de Yannis Ritsos. Bs. As., Centro Editor América Latina, S.A., 1988, p. 2.

${ }^{4}$ CASTILLO, Horacio, op cit., p. 4.

${ }^{5}$ CASTILLO, Horacio, op cit., p. 6.

${ }^{6}$ VEDOYA de GUILL'ÉN, Clara. El aspecto verbal del griego. Secc. Leng. Clásic. Aglaia, Cuadernos de Es. Clásicos N 5, Fac. Humanidades, U.N.N.E., 1972.

7 MIRAMBEL, André. Grammaire du grec moderne. Oaros, Editions Klincksieck, 1969, p. 102.

${ }^{8}$ MIRAMBEL, André, op cit., p. 99

${ }^{9}$ HUMBERT, J.Mitología griega y romana; traducc. B. O. O.; $3^{\text {a }}$ edic., Barcelona, G. Gili, 1953, p. 32.

${ }^{10}$ BULHER, Karl. La onomatopeya y la función representativa del lenquaie, trad. C.A. Fayard. (En: Cassirer E. y otros. Teoría del lenguaje y lingüística general; $3^{\text {a }}$ edic., Bs. As., Paidós, 1972, p. 80

${ }^{11}$ ELIADE, Mircea. Lo sagrado y 10 profano. Traducc. Luis Gil. Barcelona, Labor, 1970, p. 84.

12 DUTOIT, Ernest. Le thème de l'adynaton dans la poésie antique. Paris, "Les Belles Lettres", 1936.

${ }^{13}$ CICHITTI MARCONE, Vicente. Sobre las adynatas o impossibilias (un intento de explicación). Actas del IV Simposio Nac. De E.E.C.C., Fac. de Humanidades, U.N.N.E., Resistencia, Chaco, 1976, p. 63

${ }^{14}$ INDA, Cilly Mûller de El adynaton: su dimensión trascendente. Longo: Dafnis y Chloé. Revista E.E.C.C., Fac. Filosofia y Letras, Instituto de Lenguas y Lit. Clásicas, U.N.C. (en prensa). 
${ }^{15}$ Consultar: CIRLOT, J. Diccionario de símbolos. Barcelona, Labor, 1969

PEREZ RIOJA, J. Diccionario de símbolos $y$ mitos. 2a edic., Madrid, Tecnos, 1971.

${ }^{16}$ ELIADE, Mircea, op cit. p. 103 y sigs.

17 PAZ, Octavio. El arco y la lira. 3" edic., México, F.C.E., 1983, p. 185.

${ }^{18} \mathrm{y}^{19}$ CASTILLO, Horacio, op cit., p. 3.

20 "Una conversación de Y. Ritsos con A. Fostieris y T. Niarjos," en revista "llexi" (La Palabra), N8, oct. De 1982. (En: Castillo, H., op cit., p. 5.).

${ }^{21}$ PAZ, Octavio. Arte mágico. (En: Las peras del olmo; 2" edic., España, Edit. Seix Barral, 1986, p.159.)

22 PAZ, Octavio. El arco y la lira. op.cit.., p.117.

- Las etimologías apuntadas fueron tomadas del Dictionaire étymologique de la langue grecque. de R. CHANTRAINE. Paris, Klincksieck, 1968.

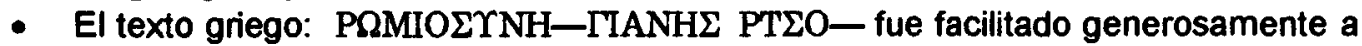
la autora del trabajo por el Dr. Horacio Castillo.

- La traducción castellana, como se consigna en el trabajo, es responsabilidad del Dr. Horacio Castillo.

- Para verificar el significado del texto neohelénico se utilizó el Diccionario griegoespañol de Hurmuziadis, J. Atenas, Sideris, 1974.

- Valiosa colaboración prestó la Gramática de griego moderno -Método intensivo y autodidáctico de S. Stanitsas- G. Nuñez, Madrid, Edic. Clásicas, 1993. 